\title{
A Review of Various Methods of Predicting Cervical Cancer
}

\author{
Geetha S. \\ Research Scholar \\ Department of Computer Science \\ Rathnavel Subramaniam College of \\ Arts and Science \\ Coimbatore
}

\author{
S. Suganya \\ Associate Professor \\ Department of Computer Science \\ Rathnavel Subramaniam College of \\ Arts and Science \\ Coimbatore
}

\begin{abstract}
Cervical Cancer is one the most threatening diseases of Indian women. According to ICMR - an institute for Cancer Prevention and Research, nearly 1, 22,844 women are affected by cervical cancer and out of that nearly 67,477 women were become victims. This malignant disease will develop in the cells of the cervix or on the neck of the uterus. But, this can be prevented and /or cured if it is diagnosed in the early stage. Due to the complexity of the cell nature, still it is a continuous problem for automating this procedure. Various algorithms and methodologies were proposed for segmenting and classifying cancer cells at the early stage into different categories. Different algorithms and methodologies are proposed by various researchers under various situations. In this paper, various research papers related to early prediction of cervical cancer are analyzed. This paper discusses Machine Learning algorithms like GLCM (Gray Level Co-occurrence Matrix), SVM (Support Vector Machines), k-NN (k-Nearest Neighbours CNNs (Convolutional Neural Networks), ), MARS (Multivariate Adaptive Regression Splines), PNNs (Probabilistic Neural Networks), spatial fuzzy clustering algorithms, Genetic Algorithm, C5.0, RFT (Random Forest Trees), Hierarchical clustering algorithm for feature extraction and CART (Classification and Regression Trees), cell segmentation and classification. The proposed work compares the merits and demerits of different algorithms which obtain good accuracy in classifying cervical cancer cells using machine learning algorithms.
\end{abstract}

\section{Keywords}

Cervical Cancer- Segmentation-Classification -Review

\section{INTRODUCTION}

Cervical cancer is the third type of cancer which has the highest death rate. For every two minutes at least one woman dies due to this terrific disease. Nearly 122,844 women are diagnosed as cervical cancer victims annually and placed $2^{\text {nd }}$ cause of female cancer [1]. Mostly the women aged between 15 to 44 are affected by this disease. In the developing countries [2], around $80 \%$ of cancer deaths happen due to cervical cancer. The cervical cancer affected women shows no symptoms which in turn decreases the survival rate. So they have to undergo another manual screening test called, PAP smear test. It is done once in three years to test whether any precancerous cells are present or not. Out of 170 types of Human Papillion Virus (HPV), HPV16 and HPV18 are the main cause for $70 \%$ of cervical cancer. The uterus and the vagina are connected by the passageway made up of three type of tissues called, Cervix. The cytologist screens the tissues manually and the test is called as PAP Smear test. The main cause of creating cancer cell is HPV16 and is detected by the Cervical Intraepithelial Neoplasia (CIN) method. Due to the few availability of experienced cytologist and more expensive, this method is not suitable for all kinds of cervical cancer patients. On analyzing, more chances for human errors leads to high false positive rates. Detecting cervical cancer using computer based system is a challenging one when segmenting the cervical cells. There are three tissues that forms the cervix layer : columnar epithelium (CE), squamous epithelium (SE) and Aceto white (AW) region. To detect the cervical cancer symptoms, the AW region turns white when it is exposed to $5 \%$ acetic acid. It is very difficult to separate the cytoplasm region and the nuclei as its cell structure has irregular boundaries. It is also difficult to find the overlapping boundaries of nucleus cells for calculating nucleus and cytoplasm ratio (NC).

\section{RELATED WORKS}

Cervical cancer is fifth among the most dangerous and deadly diseases globally, based on the mortality rate. The main reason as informed by the National Comprehensive Cancer Network (NCCN) is due to the delay in diagnosis of cervical cancer that in turn increases female fatalities even though the advanced medical facilities are available (3). Many researchers have identified several factors which are responsible for the occurrence of this deadly disease. Averbach et al. [4] have deliberated that the risk of cervical cancer is increased due to IUD. In another research, RoussetJablonski et al. [5] has claimed that risk of pelvic inflammatory diseases are increased due to IUD if it is not treated and will lead to cervical cancer. Xu et al. [6] in their research concluded that consumption of hormonal pills and smoking also leads to development of cervical cancer cells after examining the data of 886 patients. Shukla et al.; [7] insisted the same problem, long term consumption of harmonic pills will lead to several harmonic changes in women that results in cancers like breast cancers and cervical cancers. Excessive smoking will also lead to Human Papillomavirus Infection (HPV) infection and hence becomes one of the main causes of cervical cancer ([8],[9]). Parthenis et al [10] gives another reason for causes of cervical cancer is Sexually Transmitted Diseases (STDs) also leads to the same. Teame et al. [11] identified that age of the women above 38 years with STD history are becoming the victims of cervical cancer. Since no symptoms of cervical cancer are known by the women at its earlier stage, its leads to their life loss Okunowo et al [12]. Many algorithms were proposed to identify the cancer cells at its initial stage based on their images, herewith we have discussed some recent research related to it.

Mathematical Morphology $[13,14,15,16]$ is an influential technique to solve various problems in the field of Computer Vision and Image processing. Morphological operations play a vital role in extracting, manipulating, modifying the features 
the image based on their shape and size. The methods include dilation erosion, closing, opening, bottom-hat transformation, top-hat transformation, etc. In 2009, G. Jayalalitha et al.[17] use Box Counting Method and Harfa Programme software to identify the fractional dimension and calculated the variation of texture complexity and intensity of cervical cancer cells. In 2009 , C. Todd et al.[18] insisted that texture analysis is important for analyzing nuclei structure and used digitized histology images of biopsies .

Based on color features, Naganathan[19] et al used K-means algorithm for segmenting cervical cytology images. Here, color separation of the image is done by de-correlation stretching concept and grouping of classes is done by $\mathrm{K}$ means clustering. Since, K-means clustering depends on the selection of the initial centroid, it cannot provide guarantee for optimal solution. Anantha Sivprakasam et al [20] enhanced the image segmentation by using $\mathrm{L} * \mathrm{U} * \mathrm{~V}$, an unsupervised segmentation method for color transformation. In this method , the performance of K-means algorithm is enhanced with weighted and initial seeding method and also Fuzzy-C-means Clustering method for image segmentation. But its accuracy is degraded by over noise and over segmentation. Again, Anatha Sivaprakasamet al [21] proposed arithmetic and automatic thresholding concept for segmenting the cytoplasm and nucleus from cytology images. Histogram equalization, automatic contrast stretching and image arithmetic operation are used for localizing first cell nuclei. Minimum filter is used for increasing the intensity value. The main drawback of this method is over segmentation of cytoplasm and nuclei which in turn reduces segmentation accuracy.

Multiscale morphology based segmenting grey scale images was proposed by Susanta Mukhopadhyay [22]. In this method, growing ,merging and saturation are the three scales used for valid segmentation. Finally, the results of each scale segmentations are combined to get the final output. But the drawback is time consuming and need more memory space for storing the result

Thanatip Chankong et al. [23] used PAP Smear for automatic, single cervical cell segmentation and classification. This single cell image was segmented into nuclei and cytoplasm and the background used here is FCM techniques. They also used 4 main classifiers, K-nearest neighbor) KNN, (Support Vector Machine) SVM, (linear discriminant analysis) LDA, (Artificial Neural Network) ANN. This method doesn't suit for the images with multiple cells.

For distinguish the cell regions from the other background images, Asli Genctav et al. [24] proposed an unsupervised segmentation and classification method, the automatic thresholding and the morphological operations. For partitioning and segregating the nuclei from cytoplasm, the hierarchical segmentation algorithm and binary classifier are used within the cell regions. Finally, based on the cells' feature characteristics ranking will be given by calculating from the nuclei and cytoplasm regions. The main drawback is cells are not segregated when they are overlapped.

By considering the entire cell for segregating and analyzing various stages of cervical cancer instead of considering single cell, Karthigai Lakshmi [25] proposed active contour method and fuzzy thresholding. Rahmadwati et al. [26] proposed a method that combines preprocessing, nuclei and cytoplasm detection, image segmentation, feature determination and classification. Based on the morphological features and abnormality degree of the cervical cells, the images are classified into CIN1, CIN2 and CIN3. Even though the accuracy is improved in segmentation, still K-means algorithm for clustering doesn't provide optimal solutions. Laplacian of Gaussian (LoG) filter method is used by N.B Byju [27] to identify the edges of the cell nuclei from PAP Smear images. Nucleus and cytoplasm undergo segmentation and edge group detection using bi-group enhancement, proposed by Mohideen Fatima [28]. The main drawback is this method is not suitable for multiple cells and overlapping cells. Automatic segmentation of Leukocytes from nuclei using Otsu method was explained by Naveed Abbas [29]. Because of over segmentation, its accuracy differs from image to image. Marina E. Plissiti [30] proposed an automated method for the detection of boundary of cell nuclei in Pap smear images. For detecting the nuclei areas , morphological reconstruction process is applied and for segmenting the boundaries of the nuclei, watershed transform is used. Since it retrieves only the boundaries of the nuclei which is not suitable.

Mehdi et al. [31] classified the cervical cells automatically using ANN with Back-propagation (BP) method. They classified the slides of the cervical cells into mild cancer cells, moderate and severe cancer cells. During 1998, Tumer et al. detected the cervical cancer cells using radial basis function (RBF) networks [32]. They showed the experimental results for both RBF network and Multi-layer Perceptron (MLP) network. From the input Pap smear slides, the features are extracted and then fuzzy rules are applied for classifying the normal and abnormal cells was introduced by Zhong Li et al. [33]. The cervical cancer cells are predicted using the new ANN-based method was developed by Takashi et al. [34]. Royan et al. [35] proposed Artificial Neural Network and Learning Vector Quantization (LVQ). Preprocessing, filtering and feature extraction are some of the modules used to categorize the normal and abnormal cells of cervix region. $\mathrm{M}$. Kusy et al [36] proposed a gene programming which compares the MLP, probabilistic NN and RBF. In this, the chromosomes are considered as fixed length linear strings. Its structure is ordered as head and tail. The gene's length is depending on the head size, the MLP used consist of of few layers (i) input layer has the features, hidden layer has the number of nodes that are predefined and the output layer is comprised of response neurons. Usage of MLP in ANN is the technique proposed by $\mathrm{N}$. Wickramasinghe et al to perform the thinking. Due to better understanding and results, ANN architecture has one input and one output and no restriction in the number of hidden layers [37]. To overcome the cell overlapping, Babak et al proposed a novel Pap smear where cancer cells undergoes two process, preprocessing using MLP and feed forward MLPNN[38]. The hybrid approach for detecting cervical cancer was executed by Phatak et al. where they combined Support Vector Machine (SVM) and ANN [39].

Table 1 compares the merits and demerits of different algorithms which obtain good accuracy in classifying cervical cancer cells using machine learning algorithms. This table also contains the information related 
Table 1 Comparison of different cervical cancer classification algorithms

\begin{tabular}{|c|c|c|c|c|c|c|}
\hline Sl.No & Title of the paper & Author & Method & Merits & Demerits & Year \\
\hline 1 & $\begin{array}{c}\text { Enhanced Colour } \\
\text { Image Segmentation } \\
\text { on Cervical Cytology } \\
\text { Image }\end{array}$ & $\begin{array}{c}\text { Dr. E.R. } \\
\text { Naganathan, S. } \\
\text { Anantha } \\
\text { Sivaprakasam and } \\
\text { V. Saravana Kumar }\end{array}$ & $\begin{array}{l}\text { K-means } \\
\text { clustering } \\
\text { algorithm }\end{array}$ & Faster convergence & $\begin{array}{l}\text { It depends on } \\
\text { initial seed } \\
\text { Hard to obtain } \\
\text { optimal solution }\end{array}$ & 2013 \\
\hline 2 & $\begin{array}{l}\text { Segmentation of } \\
\text { Cervical Image Using } \\
\text { Unsupervised } \\
\text { Clustering } \\
\text { Algortihms with } \\
\mathrm{L}^{*} \mathrm{u}^{*} \mathrm{v} \text { Color } \\
\text { Transformation }\end{array}$ & $\begin{array}{c}\text { Anantha } \\
\text { Sivaprakasam } \\
\text { Sivaprakasam and } \\
\text { Naganathan Ealai } \\
\text { Rengasari, }\end{array}$ & $\begin{array}{l}\text { unsupervised } \\
\text { methods in } \\
\mathrm{L} * \mathrm{U} * \mathrm{~V} \text { color } \\
\text { transformation }\end{array}$ & $\begin{array}{c}\text { Image is } \\
\text { segmented using } \\
\text { fast K-Means with } \\
\text { weighted and } \\
\text { careful seeding } \\
\text { method and Fuzzy- } \\
\text { C-means clustering } \\
\text { method. }\end{array}$ & $\begin{array}{c}\text { Noise \& } \\
\text { Over } \\
\text { Segmentation } \\
\text { Reduced accuracy }\end{array}$ & 2015 \\
\hline 3 & $\begin{array}{l}\text { Automatic Cervical } \\
\text { Image Segmentation } \\
\text { using Arithmetic and } \\
\text { Threshold Concept }\end{array}$ & $\begin{array}{c}\text { Anantha } \\
\text { Sivaprakasam } \\
\text { Sivaprakasam and } \\
\text { Naganathan Ealai } \\
\text { Rengasari, }\end{array}$ & $\begin{array}{l}\text { To segment the } \\
\text { nucleus and } \\
\text { cytoplasm from } \\
\text { cytology image } \\
\text { using } \\
\text { arithmetic and } \\
\text { automatic } \\
\text { thresholding } \\
\text { concept }\end{array}$ & $\begin{array}{l}\text { Improved first cell } \\
\text { nuclei } \\
\text { the intensity value } \\
\text { of the nuclei is } \\
\text { increased using } \\
\text { Minimum filter. }\end{array}$ & $\begin{array}{l}\text { Over- } \\
\text { segmentation of } \\
\text { the nuclei and } \\
\text { cytoplasm } \\
\text { dwindle the } \\
\text { segmentation } \\
\text { accuracy. }\end{array}$ & 2014 \\
\hline 4 & $\begin{array}{l}\text { Automatic Cervical } \\
\text { Cell Segmentation } \\
\text { and Classification in } \\
\text { Pap Smears }\end{array}$ & $\begin{array}{c}\text { Thanatip } \\
\text { Chankong, Nipon } \\
\text { Theera-Umpon and } \\
\text { Sansanee, } \\
\text { Auephanwiriyakul }\end{array}$ & $\begin{array}{c}\text { Automatic } \\
\text { cervical cell } \\
\text { segmentation } \\
\text { and } \\
\text { classification in } \\
\text { Pap Smears }\end{array}$ & $\begin{array}{l}\text { single cervical cell } \\
\text { image was } \\
\text { segmented into } \\
\text { nuclei, cytoplasm } \\
\text { and background } \\
\text { using FCM } \\
\text { techniques }\end{array}$ & $\begin{array}{l}\text { Not suitable for } \\
\text { the image with } \\
\text { multiple cells }\end{array}$ & 2014 \\
\hline 5 & $\begin{array}{l}\text { Automatic Color } \\
\text { Nuclei Segmentation } \\
\text { of Leukocytes for } \\
\text { Acute Leukemia }\end{array}$ & $\begin{array}{c}\text { Naveed Abbas and } \\
\text { Dzylkifli } \\
\text { Mohamad, }\end{array}$ & $\begin{array}{c}\text { Automatic } \\
\text { segmentation } \\
\text { of nuclei of } \\
\text { Leukocytes } \\
\text { using Otsu } \\
\text { method }\end{array}$ & $\begin{array}{c}\text { Improved } \\
\text { accuracy in cell } \\
\text { classification }\end{array}$ & $\begin{array}{l}\text { Segmentation } \\
\text { accuracy differs } \\
\text { from image to } \\
\text { image because of } \\
\text { over-segmentation }\end{array}$ & 2014 \\
\hline 6 & $\begin{array}{l}\text { A Review towards } \\
\text { Evolutionary } \\
\text { multiobjective } \\
\text { optimization } \\
\text { algorithm }\end{array}$ & S. Sharma et al & $\begin{array}{l}\text { To develop } \\
\text { multi objective } \\
\text { evolutionary } \\
\text { algorithms. }\end{array}$ & $\begin{array}{c}\text { Various meta } \\
\text { heuristic technique } \\
\text { such as differential } \\
\text { evolution, Genetic } \\
\text { algorithm, } \\
\text { gravitational search } \\
\text { algorithm(GSA) } \\
\text { and particle swarm } \\
\text { optimization (PSO) } \\
\text { have been used to } \\
\text { solve multi } \\
\text { objective problems. }\end{array}$ & $\begin{array}{l}\text { Need optimization } \\
\text { to get the desired } \\
\text { robust output }\end{array}$ & 2014 \\
\hline 7 & $\begin{array}{c}\text { A Framework for } \\
\text { Diagnosing Cervical } \\
\text { Cancer Disease Based } \\
\text { on Feedforward MLP } \\
\text { Neural Network and } \\
\text { ThinPrep } \\
\text { Histopathological } \\
\text { Cell Image Features, } \\
\text { Neural Computing } \\
\text { and Applications }\end{array}$ & $\begin{array}{l}\text { Babak Sokouti, S. } \\
\text { Haghipour and A. } \\
\text { D. Tabrizi, }\end{array}$ & $\begin{array}{c}\text { Levenberg- } \\
\text { Marquardt } \\
\text { feedforward } \\
\text { MLP neural } \\
\text { network } \\
\text { (LMFFNN) }\end{array}$ & $\begin{array}{l}\text { Good agreement } \\
\text { between the expert } \\
\text { decision and values } \\
\text { gained from the } \\
\text { ANN model }\end{array}$ & $\begin{array}{l}\text { Still problems in } \\
\text { identifying the } \\
\text { boundaries of } \\
\text { overlapping cells }\end{array}$ & 2014 \\
\hline
\end{tabular}




\begin{tabular}{|c|c|c|c|c|c|c|}
\hline 8 & $\begin{array}{c}\text { Classification of } \\
\text { Images of Cervical } \\
\text { Cancer Using SVM } \\
\text { and } \\
\text { ANN Engineering, } \\
\text { issue }\end{array}$ & $\begin{array}{c}\text { A. S. Phatak and B, } \\
\text { P. A. }\end{array}$ & $\begin{array}{l}\text { Support Vector } \\
\text { Machine } \\
\text { and } \\
\text { Artificial } \\
\text { Neural } \\
\text { Network }\end{array}$ & Improved accuracy & $\begin{array}{l}\text { Extensive data } \\
\text { for manual } \\
\text { interprepation and } \\
\text { analysis } \\
\\
\text { Classification and } \\
\text { segmentation is } \\
\text { particularly } \\
\text { critical for } \\
\text { diagnosis and } \\
\text { treatment purpose. }\end{array}$ & 2015 \\
\hline 9 & $\begin{array}{l}\text { Morphological } \\
\text { Characteristics of } \\
\text { Cervical Cells for } \\
\text { Cervical Cancer } \\
\text { Diagnosis }\end{array}$ & Rahmadwati et al. & $\begin{array}{c}\text { Hybrid } \\
\text { Approach }\end{array}$ & $\begin{array}{l}\text { Improved accuracy } \\
\text { in segmentation }\end{array}$ & $\begin{array}{l}\text { Due to } \mathrm{K}- \\
\text { means algorithm } \\
\text { poor optimal } \\
\text { solution is } \\
\text { obtained. }\end{array}$ & 2010 \\
\hline 10 & $\begin{array}{l}\text { A Hybrid Image } \\
\text { Segmentation of } \\
\text { Cervical Cells by Bi- } \\
\text { group Enhancement } \\
\text { and Scan Line Filling }\end{array}$ & $\begin{array}{l}\text { Mohideen Fatima } \\
\text { et al }\end{array}$ & $\begin{array}{c}\text { Bigroup } \\
\text { enhancement }\end{array}$ & $\begin{array}{c}\text { Undergo } \\
\text { segmentation and } \\
\text { edge detection }\end{array}$ & $\begin{array}{l}\text { Not suitable for } \\
\text { overlapping cells }\end{array}$ & 2012 \\
\hline 11 & $\begin{array}{l}\text { Machine learning } \\
\text { Technique for } \\
\text { detection of } \\
\text { Cervical Cancer } \\
\text { using k-NN and } \\
\text { Artificial } \\
\text { Neural Network }\end{array}$ & $\begin{array}{l}\text { P. K. Malli, S. } \\
\text { Nandyal [40] }\end{array}$ & $\begin{array}{c}\text { K-Nearest } \\
\text { Neighbours (k- } \\
\text { NNs) } \\
\text { and Artificial } \\
\text { Neural } \\
\text { Networks } \\
\text { (ANNs). }\end{array}$ & $\begin{array}{c}\text { k-NN } \\
\text { Classification } \\
\text { and } \\
\text { Coupled fuzzy } \\
\text { based } \\
\text { segmentation }\end{array}$ & $\begin{array}{l}\text { Large accuracy } \\
\text { difference } \\
\text { for different } \\
\text { types of cells. }\end{array}$ & 2017 \\
\hline 12 & $\begin{array}{c}\text { Cervical Cancer } \\
\text { Detection and } \\
\text { Classification } \\
\text { Using Texture } \\
\text { Analysis }\end{array}$ & $\begin{array}{l}\text { M.K. Soumya, K. } \\
\text { Sneha and C. } \\
\text { Arunvinodh [41] }\end{array}$ & $\begin{array}{c}\text { Texture } \\
\text { analysis or } \\
\text { feature } \\
\text { extraction } \\
\text { using GLCM } \\
\text { and } \\
\text { cell } \\
\text { classification } \\
\text { using SVM }\end{array}$ & $\begin{array}{l}\text { Outperformed in } \\
\text { Statistical features } \\
\text { and } \\
\text { transform features }\end{array}$ & $\begin{array}{l}\text { Results differ for } \\
\text { different types of } \\
\text { images }\end{array}$ & 2016 \\
\hline 13 & $\begin{array}{l}\text { Cervical Cancer } \\
\text { Prediction using } \\
\text { Data Mining }\end{array}$ & $\begin{array}{l}\text { D. N. Punjani, K. } \\
\text { H. Atkotiya [42] }\end{array}$ & Decision Trees. & $\begin{array}{l}\text { Used to identity } \\
\text { low, moderate and } \\
\text { high level of } \\
\text { cancer for a patient }\end{array}$ & $\begin{array}{c}\text { Only general } \\
\text { attributes are used } \\
\text { Not specific } \\
\text { to cervical cancer. }\end{array}$ & 2017 \\
\hline 14 & $\begin{array}{c}\text { DeepPap: Deep } \\
\text { Convolutional } \\
\text { Networks for } \\
\text { Cervical Cell } \\
\text { Classification }\end{array}$ & $\begin{array}{l}\text { L. Zhang, L. Lu, I. } \\
\text { Nogues, R. M. } \\
\text { Summers, S. Liu et } \\
\text { al., [43] }\end{array}$ & $\begin{array}{c}\text { Convolutional } \\
\text { Neural } \\
\text { Networks } \\
\text { (CNNs) }\end{array}$ & $\begin{array}{l}\text { Deep features are } \\
\text { automatically } \\
\text { extracted from cell } \\
\text { images using CNN }\end{array}$ & $\begin{array}{l}\text { 1. Takes more } \\
\text { evaluation time } \\
\text { for single patch } \\
\text { cell approximately } \\
3.5 \text { seconds } \\
\text { 2. Nucleus center } \\
\text { is } \\
\text { required for } \\
\text { Implementation. } \\
\text { 3. Incorrect } \\
\text { classification of } \\
\text { few cells }\end{array}$ & 2018 \\
\hline
\end{tabular}




\section{CONCLUSION}

In this paper, various causes of cervical cancer followed by various methods and algorithms used for detecting cervical cancer cells at its early stage is discussed. The common problem identified in most of the researches is noise, over segmentation, obtaining poor optimal solution, not suitable for overlapping cells, classification issues etc. The research on classifying cervical cancer is not bounded to single problem, the study of complexity of cell nature need to be done in detail. This will helpful in determining the successful prediction of cervical cancer at its early stages.

\section{REFERENCES}

[1] Human Papilloma virus and Related Diseases Report India, March 20, 2015. Website: www.HPVcentere.net.

[2] http://www.cervicalcanceraction.org/whynow/about.php

[3] Koh, W.-J., Greer, B. E., Abu-Rustum, N. R., Apte, S. M., Campos, S. M., Cho, K. R., Chu, C., Cohn, D., Crispens, M. A., Dorigo, O. et al. (2015). Cervical cancer, version 2.2015, Journal of the National Comprehensive Cancer Network 13(4): 395-404,2015.

[4] Averbach, S., Silverberg, M. J., Leyden, W., SmithMcCune, K., Raine-Bennett, T. and Sawaya, G. F. (2018). Recent intrauterine device use and the risk of precancerous

[5] Rousset-Jablonski, C., Reynaud, Q., Nove-Josserand, R., Durupt, S. and Durieu, I. (Gynecological management and follow-up in women with cystic fibrosis, Revuedes maladies respiratoires 2018 .

[6] Xu, H., Egger, S., Velentzis, L. S., O’Connell, D. L., Banks, E., Darlington-Brown, J., Canfell, K. and Sitas, F "Hormonal contraceptive use and smoking as risk factors for high-grade cervical intraepithelial neoplasia in unvaccinated women aged 30-44 years: A case-control study in new south wales, Australia", Cancer epidemiology 55: 162-169, 2018.

[7] Shukla, A., Jamwal, R. and Bala, K "Adverse effect of combined oral contraceptive pills", Asian J Pharm Clin Res 10(1): 17-21, 2017.

[8] Chatzistamatiou, K., Moysiadis, T., Vryzas, D., Chatzaki, E., Kaufmann, A. M., Koch,I., Soutschek, E., Boecher, O., Tsertanidou, A., Maglaveras, N. et al. “ Cigarette smoking promotes infection of cervical cells by high-risk human papillomaviruses, but not subsequent E7 Oncoprotein expression, International journal of molecular sciences 19(2): 422, 2018.

[9] Wentzensen, N. and Arbyn, M. Hpv-based cervical cancer screening-facts, fiction, and misperceptions, Preventive medicine 98: 33-35, 2017.

[10] Parthenis, C., Panagopoulos, P., Margari, N., Kottaridi, C., Spathis, A., Pouliakis, A., Konstantoudakis, S., Chrelias, G., Chrelias, C., Papantoniou, N. et al. The association between sexually transmitted infections, human papillomavirus and cervical cytology abnormalities among women in greece, International Journal of Infectious Diseases, 2018 .

[11] Teame, H., Addissie, A., Ayele, W., Hirpa, S., Gebremariam, A., Gebreheat, G. and Jemal, A. "Factors associated with cervical precancerous lesions among women screened for cervical cancer in addis ababa, ethiopia: A case control study, PloS one" 13(1): e0191506, 2018.

[12] Okunowo, A. A., Daramola, E. S., Soibi-Harry, A. P., Ezenwankwo, F. C., Kuku, J. O., Okunade, K. S. and Anorlu, R. I. (2018). Women's knowledge of cervical cancer and Uptake of pap smear testing and the factors influencing it in a nigerian tertiary hospital, Journal of Cancer Research and Practice, 2018.

[13] Edward R. Dougherty and Jaakko T. Astola, "An Introduction to Nonlinear Image Processing", First Edition, Society of Photo-Optical Instrumentation Engineers, 1994.

[14] Gasteratos, "Mathematical Morphology Operations and Structuring Elements", In CVonline: On-Line Compendium of Computer Vision, R. Fisher(ed) Available: http://www.dai.ed.ac.uk/ CVonline/transf.htm 2001.

[15] Edward R. Dougherty and Jaakko T. Astola, "An Introduction to Nonlinear Image Processing", SPIE Optical Engineering Press, 1994.

[16] Jean Serra, "Image Analysis and Mathematical Morphology", Academic Press Inc., 1983.

[17] G. Jayalalitha and R. Uthayukumar, "Recognition of Cervical cancer based on Fractal Dimension", International Conference on Advances in Recent Technologies in Communication and Computing, 2009.

[18] C.Todd , Rahmdwati, G.Naghdy, "Cervical Cancer Classification Using Gabor Filters", First IEEE International Conference on Healthcare and Informatics, Imaging and Systems Biology, 2011

[19] Dr. E.R. Naganathan, S. Anantha Sivaprakasam and V. Saravana Kumar, "Enhanced Colour Image Segmentation on Cervical Cytology Image", Proceedings of the International Conference on Applied Mathematics and Theoretical Computer Science, pp. 215-218, 2013.

[20] Anantha Sivaprakasam Sivaprakasam and Naganathan Ealai Rengasari, "Segmentation of Cervical Image Using Unsupervised Clustering Algortihms with $\mathrm{L} * \mathrm{u} * \mathrm{v}$ Color Transformation", Asian Journal of Information Technology, Vol. 14, No. 4, pp. 147-153, 2015.

[21] S. Anantha Sivaprakasam and Dr. E.R. Naganathan, "Automatic Cervical Image Segmentation using Arithmetic and Threshold Concept", Australian Journal of Basic and Applied Sciences, Vol. 8, No. 18, pp. 283287, 2014.

[22] Susanta Mukhopadhyay and Bhabatosh Chanda, "Multiscale Morphological Segmentation of Gray-Scale Images", IEEE Transactions on Image Processing, Vol. 12, No. 5, pp. 533-549, 2003.

[23] Thanatip Chankong, Nipon Theera-Umpon and Sansanee, Auephanwiriyakul, "Automatic Cervical Cell Segmentation and Classification in Pap Smears", Computer Methods and Programs in Biomedicine, Vol. 113, No. 2, pp. 539-556, 2014.

[24] Asli Genctav, Selim Aksoy and Sevgen Onder, "Unsupervised Segmentation and Classification of Cervical Images", Pattern Recognition, Vol. 45, No. 12, pp. 4151-4168, 2012. 
[25] Karthigai Lakshmi and K Krishnaveni, "Automated Extraction of Cytoplasm and Nuclei from Cervical Cytology Images by Fuzzy Thresholding and Active Contours", International Journal of Computer Applications, Vol. 73, No. 15, pp. 26-30, 2013.

[26] Rahmadwati, G. Naghdy, M. Ros and C. Todd, "Morphological Characteristics of Cervical Cells for Cervical Cancer Diagnosis", Proceedings of the 2011 2nd International Congress on Computer Applications and Computational Science, Vol. 2, pp. 235-243, 2012.

[27] N.B. Byju, Vilayil K. Sujathan, Ptrix Malm and R. Rajesh Kumar, "A Fast and Reliable Approach to Cell Nuclei Segmentation in Pap Stained Cervical Smears", CSI Transactions on ICT, Vol. 1, No. 4, pp. 309-315, 2013.

[28] M. Mohideen Fatima alias Niraimathi and Dr. V. Seenivasagam, "A Hybrid Image Segmentation of Cervical Cells by Bi-group Enhancement and Scan Line Filling", International Journal of Computer Science and Information Technology \& Security, Vol. 2, No. 2, pp. 368-375, 2012.

[29] Naveed Abbas and Dzylkifli Mohamad, "Automatic Color Nuclei Segmentation of Leukocytes for Acute Leukemia", Research Journal of Applied Sciences, Engineering and Technology, Vol. 7, No. 14, pp. 29872993, 2014

[30] Marina E. Plissiti, Christophoros Nikou and Antonia Charchanti, "Combining Shape, Texture and Intensity Features for Cell Nuclei Extraction in Pap Smear Images", Pattern Recognition Letters, Vol. 32, No. 6, pp. $838-853,2011$

[31] M. Bazoon, D. A. Stacey, C. Cui and G. Harauz, A Hierarchical Artificial Neural Network System for the Classification of Cervical Cells

[32] Classification with ANNs, pp. 3525-3529, (1993)

[33] M. Bazoon, D. A. Stacey, C. Cui and G. Harauz, A Hierarchical Artificial Neural Network System for the Classification of Cervical Cells

[34] Classification with ANNs, pp. 3525-3529, (1993).

[35] M.Bazoon, D.A.Stacey, C Cui and G Harauz , A hierarchical Neural Network System for the classification of Cervical Cells Classification with ANN , Pp3525$3529,1993$.

[36] K. Tumer, N. Ramanujam, J. Ghosh, and R. RichardsKortum, Ensembles of Radial Basis Function Networks for Spectroscopic Detection ofCervical Precancer, IEEE Transactions on Bio-Medical Engineering, vol. 45(8), pp. 953-961, (1998). http://doi.org/10.1109/10.704864.
[37] Zhong. L. Z. Li and K. Najarian, Automated Classification of Pap Smear Test Using Neural Networks, IJCNN'01. International JointConference on Neural Networks. Proceedings (Cat. No.01CH37222), vol. 4, pp. 2899-2901, (2001).

[38] Takashi Ochi, K. Murase, T. Fujii, M. Kawamura, J. Ikezoe and T., O., . . . J., I., Survival Prediction Using Artificial Neural Networks inPatients with Uterine Cervical Cancer Treated by Radiation Therapy Alone, International Journal of Clinical Oncology, vol. 7(5), pp. 294-300, (2002).

[39] Royan. D. Aldian, E. Purwanti, and M. A. Bustomi, Applied Computing Based Artificial Neural Network for Classification of Cervical Cancer,pp. 4-7, (2013).

[40] M. Kusy, B. Obrzut and J. Kluska, Application of Gene Expression Programming and Neural Networks to Predict Adverse Events of Radical Hysterectomy in Cervical Cancer Patients, Medical \& Biological Engineering \& Computing, vol. 51(12), pp. 1357-65, (2013). http://doi.org/10.1007/s11517-013-1108-8.

[41] N. Wickramasinghe, L. Al-Hakim, C. Gonzalez and J. Tan, Service S. (Online. (2014). Lean Thinking for Healthcare, XXXII, 645 p. 178

[42] Babak Sokouti, S. Haghipour and A. D. Tabrizi, A Framework for Diagnosing Cervical Cancer Disease Based on Feedforward MLP NeuralNetwork and ThinPrep Histopathological Cell Image Features, Neural Computing and Applications, vol. 24(1), pp. 221-232, (2014).

[43] A. S. Phatak and B, P. A., Classification of Mr. Images of Cervical Cancer Using SVM and ANN Engineering, issue 2277, (2015)

[44] P. K. Malli, S. Nandyal, "Machine learning Technique for detection of Cervical Cancer using k-NN and Artificial Neural Network", International Journal of Emerging Trends \& Technology in Computer Science (IJETTCS), 2017

[45] M.K. Soumya, K. Sneha and C. Arunvinodh, "Cervical Cancer Detection and Classification Using Texture Analysis", Biomedical \& Pharmacology Journal vol. 9(2), 2016.

[46] D. N. Punjani, K. H. Atkotiya, "Cervical Cancer Prediction using Data Mining”, International Journal for Research in Applied Science \& Engineering Technology (IJRASET) , vol. 5, Issue XII, 2017.

[47] L. Zhang, L. Lu, I. Nogues, R. M. Summers, S. Liu et al., DeepPap: Deep Convolutional Networks for Cervical Cell Classification, arXiv:1801.08616v1 [cs.CV], 2018 